\title{
FORTALECER LA DOLARIZACIÓN
}

\begin{abstract}
El sistema monetario del Ecuador desde el 11 de enero de 2000, es la dolarización, mecanismo adoptado luego de que nuestra economía venía sufriendo una crisis severa con una devaluación del sucre frente al dólar americano en alrededor del 300\% y una inflación anual que superaba el 90\%, una contracción en la economía que día a día destruía empleos y expulsaba a compatriotas hacia el exterior, además de un feriado bancario y congelamiento de fondos como herencia. Desde entonces el Banco Central del Ecuador, dejo de cumplir algunas funciones primordiales como emitir monedas y billetes, que permitan tener el control de la denominada masa monetaria (dinero en poder del público, del sector público y privado incluido los bancos), tampoco poseer una política monetaria para tomar decisiones cuando así se requiera.
\end{abstract}

La dolarización por quince años ha sido una suerte de bunker que nos ha protegido de varios shocks externos, trajo con el tiempo estabilidad en precios de bienes, servicios y dinero (tasas de interés), aumentó la capacidad de pago, la calidad de vida y permite a las empresas, familias y gobierno planificar con mayor certeza a largo plazo. A estas alturas los ecuatorianos conocemos el manejo adecuado de una moneda fuerte como el dólar, sus ventajas y desventajas, por ello es fundamental fortalecer este esquema monetario para garantizar su continuidad, por ejemplo mediante la prioridad en el consumo nacional para evitar la fuga de dólares hacia el exterior, realizando operaciones financieras que permitan el ingreso de dólares "frescos" a nuestra economía, incentivando la producción local y nacional que abastezca los mercados y además pueda exportarse, también otorgando facilidades para que el ingreso de divisas por concepto de remesas que envían los migrantes desde el exterior, puedan ser invertidas en actividades productivas mediante emprendimientos personales o familiares (de Ecuador), creando escenarios y un ambiente favorable para que sea atractiva la llegada de inversión extranjera (más dólares) que permita crear nuevos negocios, más empleo y riqueza nacional, todas estas medidas permitirán introducir más dólares a la masa monetaria y garantizará la suficiente liquidez en la economía del país.

Por otro lado se puede atraer dólares al país mediante la recepción de créditos externos que reciben las empresas privadas (deuda externa privada) y el gobierno nacional (deuda externa pública), para actividades productivas. Sin duda las políticas y actividades descritas, son solamente algunas condiciones que internamente debemos generar para fortalecer el esquema monetario de dolarización, de esta manera se garantiza una cantidad suficientes de dólares y sostenibilidad y sustentabilidad de un esquema con más beneficios que costos para la economía ecuatoriana. Empero con el escenario actual debilitado por un precio del petróleo bajo, sumado a la apreciación (más valor) del dólar frente a otras divisas y la desaceleración económica de varios países a los que exportamos importantes cantidades de productos como a China, Rusia, Brasil y la Unión Europea, ha provocado que se disminuya el ingreso de dólares al país en una cifra cercana a los 7.000 millones de usd, poniendo en aprietos a todos. Por ahora el mantener a la dolarización como el esquema monetario nacional es prioridad y depende de todos estos factores, internos y externos, en lo que a los ecuatorianos nos compete, el compromiso debe ser aplicar aquellos que fortalezcan y garanticen suficientes dólares circulando casa adentro.

\section{Ec. Mg. Diego Proaño}

